\title{
Impact of Biochar on the Growth and Physiology of Tomato Grown in the Cadmium Contaminated Soil
}

\author{
Khaliq Dad $^{1}$, Muhammad Nawaz ${ }^{2 *}$, Rumsha Hassan', Kainat Javed ${ }^{2}$, Asma Shaheen ${ }^{2}$, Fengliang Zhao ${ }^{3}$, \\ Muhammad Imran ${ }^{4}$, Syed Tansir Hussain $\mathrm{Shah}^{4}$, Muhammad Faraz Anwar $^{5}$ and Muhammad Aurangzaib ${ }^{6}$
}

${ }^{1}$ Government Degree College Boys, Shah Sadar Din, Dera Ghazi Khan, Pakistan; ${ }^{2}$ Department of Environmental Sciences, Bahauddin Zakariya University, Multan, Pakistan; ${ }^{3}$ Institute of Environmental and Plant Protection, Chinese Academy of Tropical Agriculture Science, Haikou, Hainan, China; ${ }^{4}$ Soil and Water Testing Laboratory, Khanewal-58150, Punjab, Pakistan; ${ }^{5}$ Soil and Water Testing Laboratory, Faisalabad, Punjab, Pakistan; ${ }^{6}$ Department of Agronomy, UCA and ES, Islamia University, Bahawalpur.

Abstract | Heavy metals Pollutants are not only dangerous to human life but also to fauna and flora. The existence of cadmium $(\mathrm{Cd})$ in soil, atmosphere or water may unfavorably affect growth and physiology of plants. The experiment was conducted to study the impacts of biochar on the growth and physiology of tomato grown in $\mathrm{Cd}$ contaminated soil and activity of biochar in the contaminated soil. In this study different treatments of $\mathrm{Cd}$ were applied in the presence of certain portion of biochar. The order of treatments was $0 \mathrm{mg}$ $\mathrm{Cd}$ as control with biochar (12\%), low $\mathrm{Cd}(10 \mathrm{mg})$, high $\mathrm{Cd}(15 \mathrm{mg})$, low cadmium + biochar (10mg+12\%) and high cadmium + biochar $(15 \mathrm{mg}+12 \%)$ with distilled water as control. Growth and physiological parameters of plant were studied and prominent results were observed. The results showed that biochar has significant progressive effects on the growth and physiology of tomato by limiting the uptake of Cd by plants. As the concentration of $\mathrm{Cd}$ increased to high i.e. $15 \mathrm{mg} / \mathrm{kg}$ of soil, the limiting capacity of biochar was also seen less effective.

Received | December 21, 2020; Accepted | March 28, 2021; Published | June 03, 2021

*Correspondence | Muhammad Nawaz, Department of Environmental Sciences, Bahauddin Zakaryia University, Multan, Pakistan; Email: mnawaz@bzu.edu.pk

Citation | Dad, K., M. Nawaz, R. Hassan, K. Javed, A. Shaheen, F. Zhao, M. Imran, S.T.H. Shah, M.F. Anwar and M. Aurangzaib. 2021. Impact of biochar on the growth and physiology of tomato grown in the cadmium contaminated soil. Pakistan Journal of Agricultural Research, 34(2): 454-462.

DOI | http://dx.doi.org/10.17582/journal.pjar/2021/34.2.454.462

Keywords | Biochar, Cadmium, Growth, Physiology, Tomato

\section{Introduction}

$\mathrm{P}$ ollution of heavy metal limits the development and safety of agricultural goods produced in soil and can create remarkable ecological destruction to the environment. Cadmium is one of the greatest threatening components for human health as well as for environment. It is also a needless and nonrenewable component for plants (Zhu et al., 2020). Its existence in the soil is deliberated a thoughtful environmental problem chiefly due to its entrance in the human food chain with hazardous special effects on living entities (De Maria et al., 2013). Toxicity of $\mathrm{Cd}$ causes irregularities and inhibition of overall development in numerous species of plant. After extended period exposure to $\mathrm{Cd}$, roots become mucilaginous, decomposing, and browning, and disintegrating; lessening of roots and shoots elongation, rolling and chlorosis of leaves can occur (Tran and Popava, 2013).

Biochar is accepted as a soil amendment having June 2021 | Volume 34 | Issue 2 | Page 454 
the potential to improve soil management; biochar application has been shown to have a positive influence on soil properties. Biochar can change the soil microbial population, promote mycorrhizal fungi, and neutralise phytotoxic compounds in the soil (Lehmann et al., 2011). In addition, the application of biochar is suggested to increase plant growth by supplying several nutrients to growing plants or by leaching of nutrients (Graber et al., 2010; Lairdet al., 2010). Biochar is accepted as a soil amendment having the potential to improve soil management; biochar application has been shown to have a positive influence on soil properties. Biochar can change the soil microbial population, promote mycorrhizal fungi, and neutralise phytotoxic compounds in the soil (Lehmann et al., 2011). In addition, the application of biochar is suggested to increase plant growth by supplying several nutrients to growing plants or by leaching of nutrients (Graber et al., 2010; Lairdet al., 2010). Biochar can improve plant productivity directly as a result of its nutrient content and release characteristics.

Biochar is basically a charcoal resembling material that is made from plant constituents such as grass, forest and agriculturalremains that are disintegrated at very high temperature, frequently during renewable production of energy. It usually has the prospective to be utilized as a soil-conditioner and as a container substrate modification in the field of horticulture and agriculture (Basiri et al., 2019). Application of biochar to soils is deliberated as anencouragingapproach to withstandfertility of soil while instantaneously sequestering atmospheric carbon dioxide. It is also well recognized that "all types of biochars are not produced identical" and as a result the impacts on crop yields are both site particular and biochar particular (Vaccari et al., 2015). Biochar can restrain heavy-metals in soil through numerous maintenance mechanisms (Younis et al., 2015).

Biochar has numerous progressive effects on the properties of soil, such as enhancing water holding capacity of soil, enhancing cation exchange capacity, as well as addition of nutrients and develop plants nutrients uptake and biological possessions. Properties of biochar differ considerably on the behalf of their corresponding feedstock and manufacture procedure which can in turn affect their enactment in field level, farming applications, and their capability to sequester carbon (Agbna et al., 2017; Hameeda et al., 2019; Biederman and Harpole 2013). Application of biochar can improve content of organic matter in soil which usually leads to increase the fertility soil (Glodowska and Lyszcz). Biochar can modify the soil microscopic population, stimulate mycorrhizal fungi, and neutralize phytotoxic mixtures present in the soil. In addition, biochar application is recommended to intensify the growth of plants by providing numerous nutrients to raising plants or by nutrients leaching (Petrucelli et al., 2015).

Tomato (Solanumlycopersicum, L.) relates to the family known as Solanaceae also entitled Nightshades, which consist of more than three thousand species. Tomato remains to be the most significant vegetable in the whole world all because of increasing dietary and commercial worth, extensive production of tomato as well as exemplary plant to carry out research (Melomey et al., 2019). It is a significant currency and industrialized crop in several regions of the whole world (Qasim et al., 2018). Tomato contributes to a well-proportioned and healthy nutrition. They are rich in vitamins, minerals, important amino acids, dietary fibers and sugars. Tomato comprises abundant vitamin $\mathrm{B}$ as well as $\mathrm{C}$, phosphorus and iron. Tomatoes are processed fresh in salads or cooked in pastes, soup and fish or meat dishes. They can also be consumed into squashes, ketchup and juices. Preserved and dehydrated tomatoes are economically significant processed foodstuffs (Dam et al., 2005). In present study, an effort has been made in order to study the impacts of biochar on the growth and physiology of tomato grown in the cadmium contaminated soil.

\section{Materials and Methods}

The experiment was conducted in Botanical Garden, Bahauddin Zakariya University Multan during March 2020. For conducting experiment, certified seeds of tomato were taken from Cotton Research Institute of Multan. Soil was prepared after crushing, drying and stone free by sieving to $2 \mathrm{~mm}$. Before sowing of tomato, soil was spiked with $\mathrm{Cd}$ salt. Already synthesized Biochar was taken from Department of soil sciences, Bahauddin Zakariya University, Multan for experimental work. The order of concentrations of $\mathrm{Cd}$ with biochar in the form of treatments levels was control with no $\mathrm{Cd}$ and biochar, low cadmium $(10 \mathrm{mg} / \mathrm{kg}$ of soil), high cadmium $(15 \mathrm{mg} / \mathrm{kg}$ of soil), low cadmium + biochar $12 \%$ and high cadmium + biochar $12 \%$ were applied to the 
tomato plants. Growth Parameters including shoot and root length, shoot and root fresh and dry weight, leaves fresh and dry weights, number of leaves were studied. While physiological parameters were in the form of chlorophyll $\mathrm{a}$ and $\mathrm{b}$, total chlorophyll, total protein, total amino acid, total phosphorus, total potassium, total magnesium and total calcium. All the data obtained was analyzed by using the Microsoft excel for statistical analysis. Digital balance was used for the weighing the fresh and dry weights of root, shoots and leaves while chlorophyll a, b and total chlorophyll ratio were calculated by using chlorophyll meter (SPAD-502). Folin phenol reagent was used to measure protein. The analysis of amino acids was carried out with the help of an automatic amino acid analyzer. $\mathrm{Ca}, \mathrm{Mg}, \mathrm{P}$ and $\mathrm{K}$ were determined by using inductively coupled plasma atomic emission spectrometer.

\section{Results and Discussion}

\section{Impacts of biochar and Cd on growth parameters}

Results shown in the Table 1, biochar significantly reduced the impact of cadmium on the shoot length of tomato plant. Maximum shoot length $19.16 \mathrm{~cm}$ was recorded in presence of biochar. While minimum shoot length $11.23 \mathrm{~cm}$ was obtained in the presence of high cadmium. Control showed normal growth i.e. $18 \mathrm{~cm}$ of shoots while in case of shoot length biochar showed its maximum impact in reducing the toxicity of $\mathrm{Cd}$. Low cadmium showed minimum effects as more growth trend was noted, the length of shoots was $16.6 \mathrm{~cm}$ as compared to that of high level of $\mathrm{Cd}$ which showed reduction in the shoot lengths. While combination of low cadmium and biochar showed more growth in the plants $17.5 \mathrm{~cm}$ of shoots than the pants with high cadmium and biochar that was $8.5 \mathrm{~cm}$. Similar findings have been already found by many authors when biochar was used in the presence Cr (Puga et al., 2015; Abbas et al., 2017). Biochar synthesized form wheat straw has also shown strong interaction with bindings and translocation of copper and cadmium in the soil. It was observed that biochar elevated the soil fertility and increased the annual yield of rice. Biochar was also seen helpful in changing the toxic severity of $\mathrm{Cd}$ when applied in hydrated soil (Medyńska-Juraszek et al., 2020) Biochar significantly reduced the impact of cadmium on the root length of tomato plant. Maximum root length $10.43 \mathrm{~cm}$ was observed in presence of biochar solo. While minimum root length $6.3 \mathrm{~cm}$ was recorded in the presence of high cadmium. Control plants showed normal growth $9.2 \mathrm{~cm}$ of roots while application of biochar showed maximum impacts of cd on root length. Plants with low cadmium application showed more growth $7.3 \mathrm{~cm}$ of roots than the plants with high cadmium. While combination of low cadmium and biochar showed more tendency of growth in roots $8.15 \mathrm{~cm}$ than the plants with high cadmium and biochar $4.6 \mathrm{~cm}$. These results matched with the experimental study of Fiaz et al. (2014); Brennan et al. (2014) in which growth pattern in the fresh as well as root, shoot and leaves was observed high with the supplements of charcoal biochar. While Ali et al. (2019) observed the biochemical changes in the cd contaminated soil when biochar was added. The mechanism of absorption of $\mathrm{cd}$ in the soil in the presence of biochar and ions exchange were also observed by Ali et al. (2019). In case of fresh weight of tomato plants, similar impacts of biochar and cd were observed. Maximum shoot fresh weight 30.83 $\mathrm{g}$ was recorded in presence of $12 \%$ of biochar while minimum shoot fresh weight $17.5 \mathrm{~g}$ was noted in the presence of high cadmium. Control treatments showed normal shoot fresh weight of $25.3 \mathrm{~g}$ as compared to that of rest of the treatments level of cd and biochar. Biochar also showed maximum shoot fresh weight. Plants with low cadmium application showed more shoot fresh weight $24.13 \mathrm{~g}$ than the plants with high cadmium $17.5 \mathrm{~g}$. While combination of low cadmium and biochar showed more shoot fresh weight of 25.83 than the plants with high cadmium and biochar 17.8g. (Alaboudi et al., 2019; Medyńska-Juraszek et al., 2020) observed the same pattern of growth in the wheat crops and their findings have shown the in cease in the yield, biomass and leaf surface area. According to their study, low temperature also hindered the mobility of pollutants in soil surface and biochar efficiency was also elevated. It was also clear by the study of Alaboudi et al. (2019) in case of green chili when biochar and chromium were supplied together as high translocation of chromium was observed at high temperature. Biochar significantly reduced the impact of cadmium on the root fresh weight of tomato plant. Maximum root fresh weight of $9.4 \mathrm{~g}$ was obtained in presence of only biochar. While minimum root fresh weight of $4 \mathrm{~g}$ was obtained in the presence of high cadmium. Control treatments showed normal root fresh weight of $8.4 \mathrm{~g}$. Application of biochar showed maximum root fresh weight as compared to that of plants with low cd and biochar in which root fresh weight of $7.13 \mathrm{~g}$ as compared 
to that of high cd $4 \mathrm{~g}$. While combination of low cadmium and biochar showed more root fresh weight of $5.73 \mathrm{~g}$ than the plants with high cadmium and biochar 4.66g. Brennan et al. (2014); Liu et al. (2020) noted the same pattern of growth and biochemical processes during the research work on the biochar applications in the presence of copper in the soil.

Same pattern of biochar and cd treatments were observed in case of dry weights of roots, shoot and leaves. Biochar reduced the toxic impacts of $\mathrm{cd}$ in case of shoot dry weights which was found maximum $14.7 \mathrm{~g}$ in presence of biochar only. While minimum shoot dry weight of $9.2 \mathrm{~g}$ was achieved in the presence of high cadmium. Application of biochar showed maximum shoot dry weight by reducing the toxicity of $\mathrm{Cd}$. Tomato plants with low cadmium application showed more shoot dry weight of $10.8 \mathrm{~g}$ than the plants with high cadmium 9.2g. While combination of low cadmium and biochar showed more shoot dry weight of $11.8 \mathrm{~g}$ than the plants with high cadmium and biochar 7.766g. Maximum root dry weight of $6.06 \mathrm{~g}$ was observed in presence of only biochar while minimum root dry weight of $3.46 \mathrm{~g}$ was obtained due to the toxic impacts of $\mathrm{Cd}$. Plants with low cadmium application showed more root dry weight of $4.4 \mathrm{~g}$ than the plants with high cadmium $3.46 \mathrm{~g}$. While combination of low cadmium and biochar showed more root dry weight of $4.63 \mathrm{~g}$ than the pants with high cadmium and biochar $2.66 \mathrm{~g}$. Biochar significantly reduced the impact of cadmium on the leaves fresh weight of tomato plant. Maximum leaves fresh weight of $10.5 \mathrm{~g}$ was recorded in presence of only biochar. While minimum leaves fresh weight of $7.5 \mathrm{~g}$ was obtained in the presence of high cadmium. Control treatments showed normal leaves fresh weight of $10.5 \mathrm{~g}$. Plants with low cadmium application showed more leaves fresh weight of $\mathrm{C} 8.4 \mathrm{~g}$ than the plants with high cadmium $7.5 \mathrm{~g}$. Combination of low cadmium and biochar showed more leaves fresh weight of $8.66 \mathrm{~g}$ than the plants with high cadmium and biochar $6.56 \mathrm{~g}$. Biochar also elevated the leaves dry weight of $6.16 \mathrm{~g}$ at low level of $\mathrm{Cd}$ and also in single form. The combination of low level of $\mathrm{Cd}$ and biochar showed significant impacts of biochar on dry weight of leaves while in the presence of high level of $\mathrm{Cd}$ the impact of biochar was found slightly. Authors like Coumar et al. (2016); Bashir et al. (2018); Ghori et al. (2019) and Zhu et al. (2020) conducted their studies in line with the current research work and found that biochar having various compositions increased the porosity of soil by which absorption of heavy metals like $\mathrm{Cd}, \mathrm{Cu}$ and $\mathrm{Ni}$ was found very effectively. This pattern of translocation of heavy metals then shifted the critical load of such heavy metals in soil as the digestion process of biochar was occurred in the soil. This showed that biochar worked multipurpose in the soil in the presence of heavy metals. The studies of (Rehman et al., 2011; Suppadit et al., 2012; Suskabye et al., 2016; Brennan et al., 2014; Woldetsadik et al., 2016; Ghori et al.,2019; Awad et al.,2020; MedyńskaJuraszek et al., 2020) also noted the interaction of biochar with soil and pollutants particles and found the findings e.g. (i) biochar increased the fertility of soil (ii) pollutants degradation was occurred with the supplements of biochar (iii) High movement of pollutants and exchange of ions was occurred (iv) critical shifting of heavy metals load was seen within the tranlocation of biochar in the soil. The studies of these authors also confirmed the detoxification of pollutants in the presence of biochar supplied to the soil which increased the growth of plants.

\section{Impacts of biochar and Cd on physiological parameters}

The impacts of biochar in the presence of $\mathrm{Cd}$ have been shown in the Table 2 which showed the similar trends as in case of growth parameters. Biochar significantly reduced the impact of cadmium on the chlorophyll a of tomato plant. Maximum chlorophyll a $(0.51 \mathrm{mg} / \mathrm{g})$ was observed in presence of solo biochar. While minimum chlorophyll a $0.35 \mathrm{mg} / \mathrm{g}$ was obtained in the presence of high cadmium. Control treatments showed normal chlorophyll a content 0.45 $\mathrm{mg} / \mathrm{g}$. Plants under low cadmium level also showed more chlorophyll a $0.41 \mathrm{mg} / \mathrm{g}$ than the pants growing under high cadmium $0.35 \mathrm{mg} / \mathrm{g}$. Combination of low cadmium and biochar showed more chlorophyll a $0.42 \mathrm{mg} / \mathrm{g}$ than the combination of high cadmium and biochar $0.27 \mathrm{mg} / \mathrm{g}$. Biochar significantly reduced the impact of cadmium on the chlorophyll $\mathrm{b}$ of tomato plant. Maximum chlorophyll b $0.44 \mathrm{mg} / \mathrm{g}$ was obtained under biochar in single form. While minimum chlorophyll b $0.3 \mathrm{mg} / \mathrm{g}$ was obtained in the presence of high cadmium. Control group showed normal chlorophyll b content $0.41 \mathrm{mg} / \mathrm{g}$. Application of biochar on solo basis showed maximum chlorophyll b content. While combination of low cadmium and biochar showed more chlorophyll b content $0.39 \mathrm{mg} / \mathrm{g}$ than the combination of high cadmium and biochar $0.28 \mathrm{mg} / \mathrm{g}$. The total chlorophyll of tomato plant also showed the same trend of interaction under the stress of $\mathrm{Cd}$ and biochar addition. 
Table 1: Effects of biocar and heavy metals on the growth parameters of tomato plant.

\begin{tabular}{|c|c|c|c|c|c|c|c|c|c|}
\hline Treatments & $\begin{array}{l}\text { Shoot } \\
\text { length }(\mathrm{cm})\end{array}$ & $\begin{array}{l}\text { Root } \\
\text { length (cm) }\end{array}$ & $\begin{array}{l}\text { Shoot fresh } \\
\text { weight (g/ } \\
\text { plant) }\end{array}$ & $\begin{array}{l}\text { Root fresh } \\
\text { weight (g/ } \\
\text { plant) }\end{array}$ & $\begin{array}{l}\text { Shoot dry } \\
\text { weight (g/ } \\
\text { plant) }\end{array}$ & $\begin{array}{l}\text { Root dry } \\
\text { weight (g/ } \\
\text { plant) }\end{array}$ & $\begin{array}{l}\text { Leaves } \\
\text { fresh } \\
\text { weight (g) }\end{array}$ & $\begin{array}{l}\text { Leaves dry } \\
\text { weight (g) }\end{array}$ & $\begin{array}{l}\text { Number of } \\
\text { leaves }\end{array}$ \\
\hline CK & $18 \pm 0.5$ & $9.2 \pm 0.26$ & $25.3 \pm 0.43$ & $8.46 \pm 0.45$ & $13.86 \pm 0.35$ & $5.13 \pm 0.15$ & $10.5 \pm 0.5$ & $5.43 \pm 0.40$ & $24.33 \pm 0.57$ \\
\hline $\mathrm{BC}$ & $19.17 \pm 0.37$ & $10.43 \pm 0.30$ & $30.83 \pm 0.76$ & $9.4 \pm 0.36$ & $14.7 \pm 0.2$ & $6.07 \pm 0.20$ & $11.9 \pm 0.36$ & $6.16 \pm 0.15$ & $27 \pm 1$ \\
\hline $\mathrm{Cd}_{\text {low }}$ & $16.6 \pm 0.52$ & $7.3 \pm 0.45$ & $24.13 \pm 0.32$ & $7.13 \pm 0.32$ & $10.8 \pm 0.26$ & $4.4 \pm 0.36$ & $8.4 \pm 0.36$ & $5.43 \pm 0.40$ & $22 \pm 1$ \\
\hline $\mathrm{Cd}_{\text {high }}$ & $11.23 \pm 1.12$ & $6.3 \pm 0.2$ & $17.5 \pm 0.5$ & $4 \pm 0.1$ & $9.2 \pm 0.25$ & $3.47 \pm 0.45$ & $7.5 \pm 0.5$ & $4.23 \pm 0.25$ & $18 \pm 1$ \\
\hline $\mathrm{Cd}_{\text {low }+\mathrm{BC}}$ & $17.5 \pm 0.5$ & $8.15 \pm 0.30$ & $25.83 \pm 0.76$ & $5.73 \pm 0.25$ & $11.8 \pm 0.26$ & $4.63 \pm 0.15$ & $8.66 \pm 0.49$ & $5.76 \pm 0.15$ & $24 \pm 1$ \\
\hline $\mathrm{Cd}_{\text {high }+\mathrm{BC}}$ & $8.5 \pm 0.45$ & $4.6 \pm 0.43$ & $17.8 \pm 0.75$ & $4.67 \pm 0.58$ & $7.77 \pm 0.25$ & $2.67 \pm 0.15$ & $6.57 \pm 0.49$ & $3.3 \pm 0.36$ & $15.67 \pm 1.52$ \\
\hline
\end{tabular}

Table 2: Effects of biocar and heary metals on the physiological parameters of tomato plant.

\begin{tabular}{|c|c|c|c|c|c|c|c|c|c|}
\hline $\begin{array}{l}\text { Treat- } \\
\text { ments }\end{array}$ & $\begin{array}{l}\text { Chlorophyll } \\
\text { a (mg/g) }\end{array}$ & $\begin{array}{l}\text { Chlorophyll } \\
\text { b (mg/g) }\end{array}$ & $\begin{array}{l}\text { Total Chloro- } \\
\text { phyll (mg/g) }\end{array}$ & $\begin{array}{l}\text { Total } \\
\text { protein } \\
(\mathrm{mg} / \mathrm{g})\end{array}$ & $\begin{array}{l}\text { Total ami- } \\
\text { no acids } \\
\text { (mg/g) }\end{array}$ & $\begin{array}{l}\text { Total } \\
\text { phosphorus } \\
\text { (mg/g) }\end{array}$ & $\begin{array}{l}\text { Total } \\
\text { potassium } \\
\text { (mg/g) }\end{array}$ & $\begin{array}{l}\text { Total } \\
\text { Magnesium } \\
(\mathrm{mg} / \mathrm{g})\end{array}$ & $\begin{array}{l}\text { Total } \\
\text { Calcium } \\
(\mathrm{mg} / \mathrm{g})\end{array}$ \\
\hline CK & $0.45 \pm 0.02$ & $0.41 \pm 0.01$ & $0.86 \pm 0.01$ & $2.52 \pm 0.02$ & $1.48 \pm 0.02$ & $0.62 \pm 0.02$ & $1.73 \pm 0.01$ & $1.22 \pm 0.02$ & $2.11 \pm 0.02$ \\
\hline $\mathrm{BC}$ & $0.51 \pm 0.01$ & $0.44 \pm 0.01$ & $0.96 \pm 0.01$ & $2.94 \pm 0.03$ & $1.94 \pm 0.02$ & $0.79 \pm 0.01$ & $1.83 \pm 0.01$ & $1.34 \pm 0.02$ & $2.62 \pm 0.02$ \\
\hline $\mathrm{Cd}_{\text {low }}$ & $0.41 \pm 0.01$ & $0.38 \pm 0.01$ & $0.78 \pm 0.01$ & $2.18 \pm 0.10$ & $1.42 \pm 0.02$ & $0.49 \pm 0.01$ & $1.6 \pm 0.01$ & $1.05 \pm 0.05$ & $2.18 \pm 0.10$ \\
\hline $\mathrm{Cd}_{\text {high }}$ & $0.35 \pm 0.01$ & $0.3 \pm 0.01$ & $0.64 \pm 0.01$ & $1.79 \pm 0.08$ & $0.90 \pm 0.03$ & $0.34 \pm 0.03$ & $1.28 \pm 0.02$ & $0.82 \pm 0.02$ & $1.48 \pm 0.02$ \\
\hline $\mathrm{Cd}_{\text {low }+\mathrm{BC}}$ & $0.42 \pm 0.01$ & $0.39 \pm 0.01$ & $0.81 \pm 0.01$ & $3.21 \pm 0.10$ & $1.49 \pm 0.01$ & $0.58 \pm 0.01$ & $1.69 \pm 0.01$ & $1.21 \pm 0.02$ & $2.4 \pm 0.05$ \\
\hline $\mathrm{Cd}_{\text {high }+\mathrm{BC}}$ & $0.27 \pm 0.02$ & $0.28 \pm 0.01$ & $0.55 \pm 0.02$ & $1.25 \pm 0.05$ & $0.71 \pm 0.02$ & $0.29 \pm 0.01$ & $0.97 \pm 0.02$ & $0.60 \pm 0.01$ & $0.98 \pm 0.02$ \\
\hline
\end{tabular}

Maximum total chlorophyll contents of $0.96 \mathrm{mg} / \mathrm{g}$ were obtained in presence of biochar when supplied in single form. While minimum total chlorophyll content $0.64 \mathrm{mg} / \mathrm{g}$ was noted in the presence of high cadmium. Plants with low cadmium application showed more total chlorophyll $0.78 \mathrm{mg} / \mathrm{g}$ than the plants with high cadmium $0.64 \mathrm{mg} / \mathrm{g}$. While combination of low cadmium and biochar showed more total chlorophyll $0.81 \mathrm{mg} / \mathrm{g}$ than the combination of high cadmium and biochar $0.55 \mathrm{mg} / \mathrm{g}$. These results have also find same in line of results (Haouari et al., 2012; Younis et al., 2015; Abid et al., 2017; Zeeshan et al., 2020) during the working of biochar in the form of saw dust on the biochemical activities of pea plants in which they found that due to chlorosis, the chlorophyll act ivies were reduced. Similarly, the studies of (Haouari et al., 2012; Younis et al., 2015, 2016; Zafar-ul-Hye et al., 2020) have found the fast mobility of pollutants in the soil when added with biochar. In their studies they observed that after addition of biochar synthesized by leafy debris accelerated the movement of $\mathrm{Cd}$ and $\mathrm{Cu}$ in the soil solution. Such type of research was also conducted by (Haouari et al., 2012; Younis et al., 2015; Moradi et al., 2019) in which interaction of chlorophyll contents with $\mathrm{Cr}$ and bichar was seen. Chlorophyll contents were found reduced in the presence of $\mathrm{Cr}$ ions in the soil. Biochar significantly reduced the impact of cadmium on the total protein of tomato plant. Maximum total protein $2.94 \mathrm{mg} / \mathrm{g}$ was recorded in presence of biochar supplied singly. While minimum total protein $1.79 \mathrm{mg} / \mathrm{g}$ was obtained in the presence of high cadmium. Control group of plants showed normal range of total protein content 2.52 $\mathrm{mg} / \mathrm{g}$. Group of plants with low cadmium application showed more total protein $2.18 \mathrm{mg} / \mathrm{g}$ than the group of plants with high cadmium $1.79 \mathrm{mg} / \mathrm{g}$. While combination of low cadmium and biochar showed more total protein $3.21 \mathrm{mg} / \mathrm{g}$ than the group of plants with high cadmium and biochar $1.25 \mathrm{mg} / \mathrm{g}$. Similar findings were obtained in case of the total amino acids of tomato plant. Maximum $1.946667 \mathrm{mg} / \mathrm{g}$ of total amino acids was in the presence of solo addition of biochar. While less amount of $0.90 \mathrm{mg} / \mathrm{g}$ total amino acids was obtained in the presence of high cadmium. Normal amount of total amino acids content of 1.48 $\mathrm{mg} / \mathrm{g}$ was detected under control. $1.42 \mathrm{mg} / \mathrm{g}$ of total amino acid was noted in the presence of low cadmium while $0.90 \mathrm{mg} / \mathrm{g}$ was recorded at high level of $\mathrm{Cd}$. Similarly, $1.49 \mathrm{mg} / \mathrm{g}$ and $0.71 \mathrm{mg} / \mathrm{g}$ of total amino acid was recorded at low and high $\mathrm{Cd}$ in combination with biochar, respectively. Biochar also showed its impact in case of total phosphorus. Maximum total phosphorus content of $0.79 \mathrm{mg} / \mathrm{g}$ was obtained in presence of only biochar. While minimum total phosphorus content of $0.34 \mathrm{mg} / \mathrm{g}$ was obtained in the presence of high cadmium. Plants under control 
treatment showed total phosphorus content of 0.62 $\mathrm{mg} / \mathrm{g}$. Low level of $\mathrm{Cd}$ showed less effect and total phosphorus content of $0.49 \mathrm{mg} / \mathrm{g}$ than high cadmium in which $0.34 \mathrm{mg} / \mathrm{g}$ of phosphorus was noted. While under combination of low cadmium and biochar slightly higher total phosphorus content of $0.58 \mathrm{mg} / \mathrm{g}$ was found than high cadmium and biochar which was $0.29 \mathrm{mg} / \mathrm{g}$. Similar results were also obtained in case of total potassium of tomato plant. Maximum total potassium content of $1.83 \mathrm{mg} / \mathrm{g}$ was obtained in presence of only biochar. While minimum amount of total potassium content of $1.28 \mathrm{mg} / \mathrm{g}$ was obtained in the presence of high cadmium. Under control treatment total potassium content was1.73 $\mathrm{mg} / \mathrm{g}$ while at low Cd $1.6 \mathrm{mg} / \mathrm{g}$ and $1.28 \mathrm{mg} / \mathrm{g}$ at high $\mathrm{Cd}$ was obtained. At low $\mathrm{Cd}$ and high $\mathrm{Cd}$ in combination with biochar produced total potassium of $1.69 \mathrm{mg} / \mathrm{g}$ and $0.97 \mathrm{mg} / \mathrm{g}$, respectively. The result in case of total magnesium were also in same line with the rest of parameters of plants similarly $1.34 \mathrm{mg} / \mathrm{g}$ of total magnesium content obtained in presence of single application of biochar while $0.82 \mathrm{mg} / \mathrm{g}$ was obtained in the presence of high cadmium. While combination of low cadmium and biochar showed more total magnesiumcontent of $1.21 \mathrm{mg} / \mathrm{g}$ than the combination of high cadmium and biochar $0.60 \mathrm{mg} / \mathrm{g}$. Plant total calcium also showed the same trend as biochar significantly reduced the impact of cadmium on the total calcium of tomato plant. Maximum total phosphorus content of $2.62 \mathrm{mg} / \mathrm{g}$ was obtained in presence of only biochar. While minimum total calcium content of $1.48 \mathrm{mg} / \mathrm{g}$ was obtained in the presence of high cadmium. Control treatment showed normal total calcium content of $2.11 \mathrm{mg} / \mathrm{g}$. Low and high levels of $\mathrm{Cd}$ in combination with biochar showed $2.18 \mathrm{mg} / \mathrm{g}$ and $0.98 \mathrm{mg} / \mathrm{g}$ of total calcium respectively. Previously similar type of results were also presented by (Khan et al., 2018; Gondek et al., 2019; Almaroai and Eissa, 2020) during their work on the elevating effects of biochar and biochar produced antagonistic effects on the combinations of different heavy metals. Younis et al. (2015); Shahkolaie et al. (2020) proved the strong contribution of biochar when supplied in the presence of some organic complexes in the saline soil and found that biochemical parameters of cotton cultivars were altered. Research work of (Sehar et al., 2018; Gondek et al., 2019) also have reported the similar findings of association of biochar and some heavy metals. Similar type of work has also been conducted by (Suskabye et al., 2012; Gondek et al., 2019) in which biochemical and growth parameters of alfalfa plants showed the elevated growth after supplementation of biochar while already $\mathrm{Cd}, \mathrm{Zn}, \mathrm{Cu}$ has impacted the plants adversely.

\section{Conclusions and Recommendations}

From the present research work it can be concluded that $\mathrm{Cd}$ which belongs to family of heavy metals has adverse impacts on the biological activates more or less. The impacts of $\mathrm{Cd}$ can be encountered by the addition of biochar. The addition of biochar minimized the effects of $\mathrm{Cd}$ in this study. Low and high levels of $\mathrm{Cd}$ supplied singly effected the growth and biochemical parameters of tomato plants while in combination with biochar, their effects were minimized to a greater extent. Biochar with low $\mathrm{Cd}$ did not allow it to produce drastic impacts on the growth and physiological activities of tomato plant while along with high level of $\mathrm{Cd}$, although $\mathrm{Cd}$ produced negative impacts but these were very less as compared to that of high level of $\mathrm{Cd}$ when it was supplied in solo form. So, from these results it is evident that biochar can be helpful in eliminating the impacts of different pollutants in soil.

\section{Novelty Statement}

Biochar can minimize the adverse impacts of toxic heavy metals.

\section{Author's Contribution}

Khaliq Dad: Planned the work.

Muhammad Nawaz: Overall supervised.

Rumsha Hassan: Wrote the article.

Kainat Javed: Preformed statistical analysis.

Asma Shaheen: Collected data.

Fengliang Zhao: Suggestions and reviewed.

Muhammad Imran: Analyzed parameters

Syed Tansir Hussain Shah: Helped in write up.

Muhammad Faraz Anwar: Corrected and revised.

Muhammad Aurangzaib: Conducted experiments.

\section{Conflict of interest}

The authors have declared no conflict of interest.

\section{References}

Abbas, T., M. Rizwan, S. Ali, M. Zia-ur-Rehman, M.F. Qayyum, F. Abbas and Y.S. Ok. 2017. Effect of biochar on cadmium bioavailability and 
uptake in wheat (Triticumaestivum L.) grown in a soil with aged contamination. Ecotoxicol. Environ. Saf., 140: 37-47. https://doi. org/10.1016/j.ecoenv.2017.02.028

Abid,M., S. Danish, M.Zafar-ul-Hye, M. Shaaban, M.M.Iqbal,A. Rehim and M.N.Naqqash.2017. Biochar increased photosynthetic and accessory pigments in tomato (Solanumlycopersicum L.) plants by reducing cadmium concentration under various irrigation waters. Environ. Sci. Pollut. Res., 24(27): 22111-22118. https://doi. org/10.1007/s11356-017-9866-8

Agbna, H.D., G. Ali, E. Albashir, M. Mohammed, M. Bakir, A. Osman and A. Elshaikh. 2017. Effect of biochar on some soil properties and tomato growth under saline water conditions. Int. J. Sci. Eng. Res., 8: 24-28.

Alaboudi, K.A., B. Ahmed and G. Brodie. 2019. Effect of biochar on $\mathrm{Pb}, \mathrm{Cd}$ and $\mathrm{Cr}$ availability and maize growth in artificial contaminated soil. Ann. Agric. Sci., 64(1): 95-102. https:// doi.org/10.1016/j.aoas.2019.04.002

Ali, S., M. Rizwan, S. Noureen, S. Anwar, B. Ali, M. Naveed and P. Ahmad. 2019. Combined use of biochar and zinc oxide nanoparticle foliar spray improved the plant growth and decreased the cadmium accumulation in rice (Oryza sativa L.) plant. Environ. Sci. Pollut. Res., 26(11): 1128811299. https://doi.org/10.1007/s11356-01904554-y

Almaroai, Y.A. and M.A. Eissa. 2020. Effect of biochar on yield and quality of tomato grown on a metal-contaminated soil. Sci. Hortic., 265: 109210. https://doi.org/10.1016/j. scienta.2020.109210

Awad, M., M. Moustafa-Farag, L. Wei, Q. Huang and Z. Liu. 2020. Effect of garden waste biochar on the bioavailability of heavy metals and growth of Brassica juncea (L.) in a multicontaminated soil. Arab. J. Geosci., 13: 439. https://doi.org/10.1007/s12517-020-05376-w

Bashir, A., M. Rizwan, S. Ali, M.Z. Rehman, W. Ishaque, M.A. Riaz and A. Maqbool. 2018. Effect of foliar-applied iron complexed with lysine on growth and cadmium $(\mathrm{Cd})$ uptake in rice under $\mathrm{Cd}$ stress. Environ. Sci. Pollut. Res., 25(21): 20691-20699. https://doi. org/10.1007/s11356-018-2042-y

Basiri Jahromi, N., A. Fulcher and F. Walker. 2019. What is biochar and how different biochars can improve your crops. UT Extension Publication,
Knoxville, pp. 829.

Biederman, L.A. and W.S. Harpole. 2013. Biochar and its effects on plant productivity and nutrient cycling: A meta-analysis. GCB Bioenergy, 5(2): 202-214. https://doi.org/10.1111/gcbb.12037

Brennan, A., E.M. Jiménez, M. Puschenreiter, J.A. Alburquerque and C. Switzer. 2014. Effects of biochar amendment on root traits and contaminant availability of maize plants in a copper and arsenic impacted soil. Plant Soil, 379(1-2): 351-360. https://doi. org/10.1007/s11104-014-2074-0

Coumar, M.V., R.S. Parihar, A.K. Dwivedi, J.K. Saha, S. Rajendiran, M.L. Dotaniya and S. Kundu. 2016. Impact of pigeon pea biochar on cadmium mobility in soil and transfer rate to leafy vegetable spinach. Environ. Monit. Assess., 188(1): 31. https://doi.org/10.1007/ s10661-015-5028-y

Dam, B.V., M.D. Goffau,J.V. Lidth de Jeude and S. Naika.2005. Cultivation of tomato: Production, processing and marketing. Agromisa/CTA.

De Maria, S., M. Puschenreiter and A.R. Rivelli. 2013. Cadmium accumulation and physiological response of sunflower plants to $\mathrm{Cd}$ during the vegetative growing cycle. Plant, Soil Environ., 59(6), 254-261. https://doi. org/10.17221/788/2012-PSE

Fiaz, K., S. Danish, U. Younis, S.A. Malik, M.H.R. Shah and S. Niaz. 2014. Drought impact on Pb/ $\mathrm{Cd}$ toxicity remediated by biochar in Brassica campestris. J. Soil Sci. Plant Nutr., 14(4): 845-854. https://doi.org/10.4067/S071895162014005000067

Ghori, S.A., S. Gul, S. Tahir, M. Sohail, S. Batool, M.N. Shahwani and G. Bano. 2019. Woodderived biochar influences nutrient use efficiency of heavy metals in spinach (Spinaciaoleracea) under groundwater and wastewater irrigation. J. Environ. Eng. Lands. Manage., 27(3): 144-152. https://doi.org/10.3846/jeelm.2019.10792

Glodowska, M. and M. Lyszcz. 2012. Biochar characteristics and application in the agriculture. Gondek, K., M. Mierzwa-Hersztek, M. Kopeć, J. Sikora, T. Głąb and K. Szczurowska. 2019. Influence of biochar application on reduced acidification of sandy soil, increased cation exchange capacity, and the content of available forms of K, Mg, and P. Pol. J. Environ. Stud., 28(1): 1-9. https://doi.org/10.15244/pjoes/81688

Graber, E.R., Y. Meller, M. Kolton, E. Cytryn, A. 
Silber,D.David,L. Tsechansky,M.Borenshtein, Y. Elad. 2010. Biochar impact on development and productivity of pepper and tomato grown in fertigated soilless media. P. Soil., (337):481496.

Hameeda, S. Gul, G. Bano, M. Manzoor, T.A. Chandio and A.A. Awan. 2019. Biochar and manure influences tomato fruit yield, heavy metal accumulation and concentration of soil nutrients under wastewater irrigation in arid climatic conditions. Cogent Food Agric., 5(1): 1576406. https://doi.org/10.1080/23311932.2 019.1576406

Haouari, C.C., A.H. Nasraoui, D. Bouthour, M.D. Houda, C.B. Daieb,J.Mnai and H. Gouia. 2012. Response of tomato (Solanumlycopersicon) to cadmium toxicity: growth, element uptake, chlorophyll content and photosynthesis rate. Afr. J. Plant Sci., 6(1): 1-7. https://doi. org/10.5897/AJPS11.107

Khan, M.A., X. Ding, S. Khan, M.L. Brusseau, A. Khan and J. Nawab. 2018. The influence of various organic amendments on the bioavailability and plant uptake of cadmium present in mine-degraded soil. Sci. Total Environ., 636: 810-817. https://doi. org/10.1016/j.scitotenv.2018.04.299

Laird, A., A. David, C..Pierce, F. Dedrick, D. Davis, R. Horton, B.Wang, D. Karlena.2010. Impact of biochar amendments on the quality of a typical Midwestern agricultural soil. Geoderma.,158(3-4): 443-449.

Liu, W., Y. Li, Y. Feng, J. Qiao, H. Zhao, J. Xie and S. Liang. 2020. The effectiveness of nanobiochar for reducing phytotoxicity and improving soil remediation in cadmium-contaminated soil. Sci. Rep., 10(1): 1-10. https://doi. org/10.1038/s41598-020-57954-3

Lehmanna, J., C. Matthias, R. Janice, T. Caroline, A. Masielloc, W. C. Hockadayd, D. Crowley. 2011. Biochar effects on soil biota - A review. Soil Bio and Bioche., 43(9): 1812-1836.

Medyńska-Juraszek, A., P.A. Rivier, D. Rasse and E.J. Joner. 2020.Biochar Affects Heavy Metal Uptake in Plants through Interactions in the Rhizosphere. Appl. Sci., 10(15): 5105. https:// doi.org/10.3390/app10155105

Melomey, L.D., A. Danquah, S.K. Offei, K. Ofori, E. Danquah and M. Osei. 2019. Review on tomato (Solanumlycopersicum L.) improvement programmes in Ghana. Recent Adv. Tomato
Breed. Prod., pp.49.

Moradi, R., N. Pourghasemian and M. Naghizadeh. 2019. Effect of beeswax waste biochar on growth, physiology and cadmium uptake in saffron. J. Cleaner Prod., 229: 1251-1261. https://doi.org/10.1016/j.jclepro.2019.05.047

Petruccelli,R.,A.Bonetti,M.L.Traversi,C.Faraloni, M. Valagussa and A. Pozzi. 2015. Influence of biochar application on nutritional quality of tomato (Lycopersiconesculentum). Crop Pasture Sci., 66(7): 747-755. https://doi. org/10.1071/CP14247

Puga, A.P., C.A. Abreu, L.C.A., Melo and L. Beesley. 2015. Biochar application to a contaminated soil reduces the availability and plant uptake of zinc, lead and cadmium. J. Environ. Manage., 159: 86-93. https://doi. org/10.1016/j.jenvman.2015.05.036

Qasim, M., W. Farooq and W. Akhtar. 2018. Preliminary report on the survey of tomato growers in Sindh, Punjab and Balochistan.

Rehman, F., F.A. Khan, D. Varshney, F. Naushin and J. Rastogi. 2011. Effect of cadmium on the growth of tomato. Biol. Med., 3(2): 187-90.

Sehar, A., R. Aziz, M.T. Rafiq, M.M. Hussain, M. Rizwan, A.K. Sehrish and S. Ali. 2018. Synthesis of biochar from sugarcane filter-cake and its impacts on physiological performance of lettuce (Lettuce sativa) grown on cadmium contaminated soil. Arab.J. Geosci., 11(20): 634. https://doi.org/10.1007/s12517-018-4006-4

Shahkolaie, S., M. Baranimotlagh, E. Dordipour, F.Khormali. 2020. Effects of inorganic and organic amendments on physiological parameters and antioxidant enzymes activities in Zea mays L. from a cadmium-contaminated calcareous soil. South Afri. J. Botany., 128(1): 132-140.

Suksabye, P., P. Thiravetyan, W. Nakbanpote. 2012. Column study of chromium (VI) adsorption from electroplating industry by coconut coir pith. J. Hazardous Materials., 160, 56 - 62.

Suksabye, P., A. Pimthong, P. Dhurakit, P. Mekvichitsaeng and P. Thiravetyan. 2016. Effect of biochars and microorganisms on cadmium accumulation in rice grains grown in $\mathrm{Cd}$-contaminated soil. Environ. Sci. Pollut. Res., 23(2): 962-973. https://doi.org/10.1007/ s11356-015-4590-8

Suppadit, T., V. Kitikoon, A. Phubphol and P. Neumnoi. 2012. Effect of quail litter biochar 
on productivity of four new physic nut varieties planted in cadmium-contaminated soil. Chilean J. Agric. Res., 72(1): 125. https:// doi.org/10.4067/S0718-58392012000100020

Tran, T.A. and L.P. Popova. 2013. Functions and toxicity of cadmium in plants: Recent advances and future prospects. Turk. J. Bot., 37(1): 1-13.

Vaccari, F.P., A. Maienza, F. Miglietta, S. Baronti, S. Di Lonardo, L. Giagnoni and G. Valboa. 2015. Biochar stimulates plant growth but not fruit yield of processing tomato in a fertile soil. Agric. Ecosyst. Environ., 207: 163-170. https://doi.org/10.1016/j.agee.2015.04.015

Woldetsadik, D., P. Drechsel, B. Keraita, B. Marschner, F. Itanna and H. Gebrekidan. 2016. Effects of biochar and alkaline amendments on cadmium immobilization, selected nutrient and cadmium concentrations of lettuce (Lactuca sativa) in two contrasting soils. Springer Plus, 5(1): 397. https://doi.org/10.1186/ s40064-016-2019-6

Younis, U., S.A. Malik, M.F. Qayyum, M.H.R. Shah, A.N. Shahzad and S. Mahmood. 2015. Biochar affects growth and biochemical activities of fenugreek (Trigonellacorniculata) in cadmium polluted soil. J. App. Bot. Food Qual., 88: 29-33.

Younis, U., S.A. Malik, M. Rizwan, M.F. Qa- yyum, Y.S. Ok, M.H.R. Shah and N. Ahmad. 2016. Biochar enhances the cadmium tolerance in spinach (Spinaciaoleracea) through modification of $\mathrm{Cd}$ uptake and physiological and biochemical attributes. Environ. Sci. Pollut. Res., 23(21): 21385-21394. https://doi. org/10.1007/s11356-016-7344-3

Zafar-ul-Hye, M., M. Naeem, S. Danish, M.J. Khan, S. Fahad, R. Datta and M.A. E1Esawi. 2020. Effect of cadmium-tolerant rhizobacteria on growth attributes and chlorophyll contents of bitter gourd under cadmium toxicity. Plants, 9(10): 1386. https:// doi.org/10.3390/plants9101386

Zeeshan, M., W. Ahmad, F. Hussain, W. Ahamd, M. Numan, M. Shah and I. Ahmad. 2020. Phytostabalization of the heavy metals in the soil with biochar applications, the impact on chlorophyll, carotene, soil fertility and tomato crop yield. J. Cleaner Prod., 255: 120318. https://doi.org/10.1016/j.jclepro.2020.120318

Zhu, Y., H. Wang, X. Lv, Y. Zhang and W. Wang. 2020. Effects of biochar and biofertilizer on cadmium-contaminated cotton growth and the antioxidative defense system. Sci. Rep., 10(1): 1-12. https://doi.org/10.9734/ JSRR/2016/23374 